\title{
Vitamin D deficiency as a risk factor for the development of autoantibodies in patients with ASIA and silicone breast implants: a cohort study and review of the literature
}

\author{
Maartje J. L. Colaris ${ }^{1,2}$ • Rene R. van der Hulst ${ }^{1,2}$ • Jan Willem Cohen Tervaert ${ }^{1,3}$
}

Received: 19 January 2017 /Revised: 14 February 2017 / Accepted: 21 February 2017 / Published online: 17 March 2017

(C) The Author(s) 2017. This article is published with open access at Springerlink.com

\begin{abstract}
The development of autoimmunity and/or autoimmune diseases is multifactorial. Vitamin D is one of the factors that might play a role. We postulated that both the presence of adjuvants and insufficient levels of vitamin D may result in the development of autoimmunity in patients with autoimmune/ inflammatory syndrome induced by adjuvants (ASIA) in relation to silicone implant incompatibility. We measured vitamin D levels in 135 patients with ASIA in relation to silicone implant incompatibility and related findings to the presence of autoantibodies that are commonly used to diagnose systemic autoimmune diseases. Furthermore, we systematically reviewed the literature regarding vitamin D deficiency as a risk factor for the development of autoantibodies. Vitamin D measurements were available for analysis in 131 of 135 patients with ASIA in relation to SIIS. Twenty-three patients (18\%) tested positive for autoantibodies, from which 18 patients $(78 \%)$ had either a vitamin D deficiency or insufficiency (median vitamin D level $60.5 \mathrm{mmol} /$ L), whereas five patients (22\%) had sufficient vitamin D levels. The risk to develop autoantibodies was significantly increased in vitamin D deficient and/or insufficient patients [RR 3.14; 95\% CI, 1.24-7.95; $p=0.009$ ]. Reviewed literature suggested an association between vitamin $\mathrm{D}$ levels and the presence and/or titer levels of autoantibodies in different autoimmune diseases. From our current study and from our review of the literature, we
\end{abstract}

Jan Willem Cohen Tervaert

jw.cohentervaert@maastrichtuniversity.nl

1 Faculty of Health, Medicine and Life Sciences, Maastricht University, Universiteitssingel 406229 ER, Maastricht, the Netherlands

2 Department of Reconstructive, Plastic and Hand Surgery, Maastricht University Medical Center, Maastricht, the Netherlands

3 Clinical and Experimental Immunology, Reinaert Clinic, Maastricht, the Netherlands conclude that vitamin D deficiency is related to the presence of autoantibodies. Whether vitamin D supplementation results in a decrease of autoimmunity needs to be studied prospectively.

Keywords Autoantibodies · Autoimmune diseases $\cdot$ Vitamin D $\cdot$ Vitamin D deficiency $\cdot$ Vitamin D supplementation

\section{Introduction}

Silicone breast implants may be associated with nonspecific symptoms such as fatigue, myalgia, arthralgia, pyrexia, dry mouth, dry eyes, and cognitive impairment [1-3]. Explantation of the breast implants results in improvement of the symptoms in $50-80 \%$ of the patients $[1,4]$. At present, it is still controversial whether silicone-filled breast implants increase the risk of autoimmunity $[3,5,6]$. Recently, however, it has been suggested that an increased prevalence of autoimmune diseases such as rheumatoid arthritis and Sjögren's syndrome exists in these patients [6]. Moreover, immune deficiency may occur in these patients at an increased frequency [3]. Finally, several autoantibodies have been reported to occur in silicone breast implant patients at an increased frequency [7-11]. Also, these findings are, however, controversial [11, 12].

Vitamin D is known to be a crucial factor in the calcium homeostasis. Vitamin D, however, is also essential for immunity. Importantly, vitamin D deficiency may represent a global health problem that has been underestimated for many years [13]. Over the last decades, it has been shown that vitamin D deficiency is associated with an increased risk for infectious diseases [14]. Moreover, a number of autoimmune diseases, including multiple sclerosis, type I diabetes, inflammatory bowel disease, systemic lupus erythematosus, and rheumatoid arthritis, are reported to be associated with vitamin D deficiency [15-17]. 
Several mechanisms by which vitamin $\mathrm{D}$ acts as a regulatory agent for the innate as well as the adaptive immune system have been described [18]. Firstly, cells of the immune system have been shown to be direct targets of vitamin D metabolites. Secondly, many immune cells contain enzymes of the cytochrome P (CYP) family and are thus able to convert 25(OH)D into calcitriol, the biologically active form of vitamin $\mathrm{D}[18,19]$.

Since vitamin D is known to be a potent regulator of the immune system [18] and vitamin D deficiency is hypothesized to contribute to B cell hyperactivity [19], we postulate that vitamin D deficiency is a risk factor for the development of autoantibodies in patients with autoimmune/inflammatory syndrome induced by adjuvants (ASIA) in relation to silicone implant incompatibility syndrome (SIIS) [3, 20]. To study this, we examined vitamin D levels in patients with ASIA in relation to SIIS and related findings to the presence of autoantibodies. Furthermore, we reviewed the effect of vitamin D deficiency as a risk factor for the development and/or production of autoantibodies.

\section{Patients and methods}

\section{Study population}

One hundred thirty-five consecutive ASIA in relation to SIIS patients were included in the current study. The patients were prospectively evaluated between January 2014 and September 2015 by one of us (JWCT). A diagnosis of ASIA was made based on criteria as previously described [2]. In short, patients were diagnosed as suffering from ASIA when either two major or one major and two minor criteria were present. Criteria are summarized in Table 1.

\section{Laboratory investigation}

All patients underwent laboratory evaluations including measurements of vitamin D, antinuclear antibodies (ANA), antibodies to extractable nuclear antigens (ENA), anti-cardiolipin antibodies (anti-CL), anti- $\beta 2$ glycoprotein- 1 antibodies, antineutrophil cytoplasmic antibodies (ANCA), IgM rheumatoid factor (RF), and anti-cyclic citrullinated peptide (anti-CCP) antibodies [21-27]. If a positive ANA was found, serum was tested for anti-double-stranded DNA antibodies (anti-dsDNA) [26], and if the ANCA test was positive, samples were additionally tested for PR3-ANCA and MPO-ANCA [25].

Vitamin D status was evaluated by measurement of serum $25(\mathrm{OH}) \mathrm{D}$ levels with a chemiluminescent immunoassay method by Roche Cobas, Roche, Basel, Switzerland. Serum 25(OH)D levels below $50 \mathrm{nmol} / \mathrm{L}(20 \mathrm{ng} / \mathrm{mL})$ were considered as vitamin D deficiency. Vitamin D insufficiency was defined as $\geq 50$ and $<75 \mathrm{nmol} / \mathrm{L}(21-29 \mathrm{ng} / \mathrm{mL})$, whereas vitamin D sufficiency was defined as $\geq 75 \mathrm{nmol} / \mathrm{L}(30 \mathrm{ng} / \mathrm{mL})[28,29]$.
Table 1 Criteria for the diagnosis of ASIA

Major criteria

- Exposure to an external stimulus (infection, vaccine, silicone, adjuvant) prior to clinical manifestations.

- The appearance of "typical" clinical manifestations: Myalgia, myositis, or muscle weakness Arthralgia and/or arthritis

Chronic fatigue, un-refreshing sleep, or sleep disturbances

Neurological manifestations (especially associated with demyelination)

Cognitive impairment, memory loss

Pyrexia, dry mouth

- Removal of inciting agent induces improvement.

- Typical biopsy of involved organs

Minor criteria:

The appearance of autoantibodies or antibodies directed at the suspected adjuvant

- Other clinical manifestations (i.e., irritable bowel syndrome)

- Specific HLA (i.e., HLA DRB1, HLA DQB1)

- Evolvement of an autoimmune disease (i.e., multiple sclerosis, systemic sclerosis)

ASIA autoimmune/inflammatory syndrome induced by adjuvants

\section{Statistical analysis}

For statistical analysis of the results, a chi-square test with a 0.05 two-sided significance level was used (SPSS 22.0 software, IBM Corp, Armonk, NY).

\section{Review}

\section{Type of studies and outcome measures}

All types of studies comparing vitamin D status and autoantibodies in patients with or without autoimmune diseases were included in this review. Meta-analysis and systematic review articles were excluded. Only articles published in English were used.

A full paper review was performed when abstracts described vitamin D levels in relation to the presence of autoantibodies and/or antibody titers. Exclusion of articles was based on the absence of (statistical) analysis of the (possible) association between serum vitamin $\mathrm{D}$ levels and the presence of autoantibodies and/or antibody titers.

\section{Search methods}

A search in MEDLINE, PubMed, and the Cochrane database from their inception to February 2016 was performed. The used search terms in the PubMed NLM catalog Medical Subject Heading database relevant to this review were "Vitamin D," "Vitamin D [Mesh]," "Vitamin D deficiency [Mesh]," "Autoantibodies," and "Autoantibodies [Mesh]." Abstracts from 176 search hits were screened for eligibility. 


\section{Study selection}

Titles and abstracts were screened for eligibility according to the inclusion criteria by the first author. When included outcome measures were unclear after regarding the abstract, articles were retrieved in full text for additional assessment. After screening the 176 PubMed abstracts according to the inclusion criteria, 38 articles were retrieved for full paper review. Also, a manual search of the reference lists of the selected articles was performed, which resulted in 19 additional articles for the full paper review. Only published data were used. A total of 57 articles were retrieved for detailed full paper review. Criteria for exclusion were met in 10 articles, leaving 47 articles that were included in the final systematic review. A flow diagram of the selection process is shown in Fig. 1.

\section{Data extraction}

Data relevant to the pre-stated outcome measures, the characteristics of the study, participants, and relevant statistical analysis of a (possible) association between the outcome measures were abstracted for this review.

\section{Results}

Vitamin D measurements were available for analysis in 131 of 135 patients with ASIA in relation to SIIS (Table 2). Thirtythree patients $(25 \%)$ presented with vitamin D deficiency $(<50 \mathrm{nmol} / \mathrm{L}), 37(28 \%)$ with vitamin D insufficiency $(\geq 50$ and $<75 \mathrm{nmol} / \mathrm{L}$ ), and 61 (47\%) with vitamin D sufficiency $(\geq 75 \mathrm{nmol} / \mathrm{L}$ ). No differences were observed in clinical characteristics between groups.

Fig. 1 Flow diagram of study enrolment in this review
Twenty-three patients (18\%) tested positive for autoantibodies. In these 23 patients, one or more antibodies were detected (Table 3). Eighteen of these patients (78\%) had either a vitamin $\mathrm{D}$ deficiency or insufficiency (median vitamin $\mathrm{D}$ level $60.5 \mathrm{mmol} / \mathrm{L})$, whereas five patients $(22 \%)$ had sufficient vitamin D levels. The risk to develop autoantibodies was significantly increased in vitamin D deficient and/or insufficient patients [RR 3.14; 95\% CI, 1.24-7.95; $p=0.009$ ].

\section{Review}

Forty-seven studies were reviewed (17 case-control studies, 19 cross-sectional studies, 1 cross-sectional case-control study, 10 cohort studies). The selected articles will be presented according to five subcategories: autoimmune thyroid diseases, connective tissue diseases, inflammatory arthritides, multiple sclerosis, and other studies.

\section{Autoimmune thyroid diseases}

In several epidemiological studies, the association between vitamin D levels and the presence of autoimmune thyroid diseases (AITDs) has been investigated [30]. Kivity et al. examined serum vitamin $\mathrm{D}$ levels in relation to anti-thyroid peroxidase (anti-TPO) and anti-thyroglobulin (anti-TG) antibodies in 92 patients with thyroid diseases (28 patients with Hashimoto's thyroiditis, 22 patients with Graves' disease, 42 patients without evidence for autoimmunity) and 98 age-matched healthy control subjects [31]. They documented a significantly higher prevalence of vitamin D deficiency $(<10 \mathrm{ng} / \mathrm{mL})$ in patients with thyroid diseases (58/92) compared to healthy controls $(30 / 98)(p<0.001)$. Vitamin D deficiency was present particularly in patients with

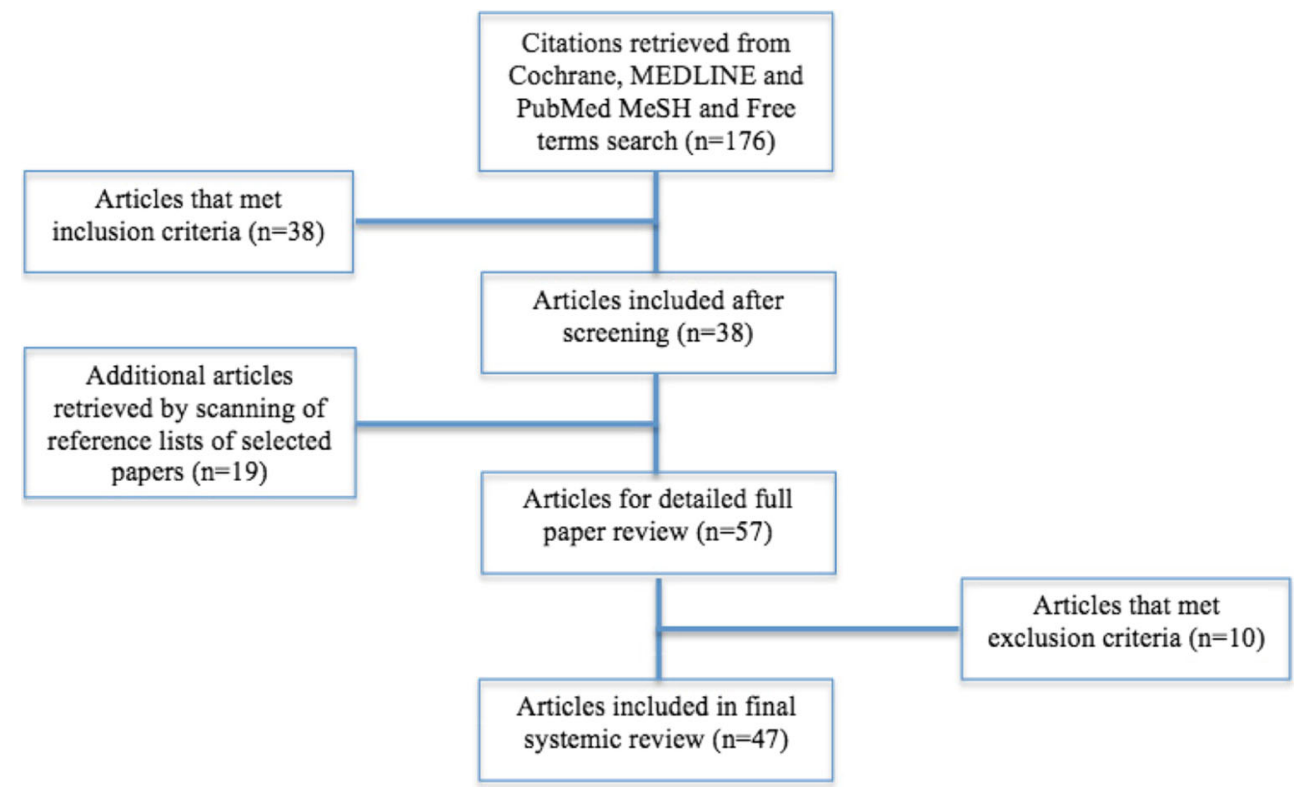


Table 2 The presence of clinical manifestations in vitamin D subgroups

\begin{tabular}{llll}
\hline Symptom & Vitamin & No. of patients \\
& $\begin{array}{l}\text { V deficiency } \\
(<50 \mathrm{nmol} / \mathrm{L}) \\
n=33\end{array}$ & $\begin{array}{l}(\geq 50-75 \mathrm{nmol} / \mathrm{L}) \\
n=37\end{array}$ & $\begin{array}{l}\text { V sufficiency } \\
(\geq 75 \mathrm{nmol} / \mathrm{L}) \\
n=61\end{array}$ \\
\hline Myalgia, myositis, or muscle weakness & 18 & 17 & 41 \\
Arthralgia and/or arthritis & 31 & 33 & 58 \\
Fatigue, unrefreshing sleep or sleep disturbances & 32 & 7 & 60 \\
Neurological manifestations & 7 & 30 & 16 \\
Cognitive impairment, memory loss & 25 & 22 & 47 \\
Pyrexia & 23 & 24 & 48 \\
Dry eyes and/or dry mouth (sicca) & 27 & & 47 \\
\hline
\end{tabular}

${ }^{a}$ Neurological manifestations: TIA/CVA or demyelination

Hashimoto's thyroiditis $(22 / 28 ; p=0.001)$ and in patients with Graves' disease $(14 / 22 ; p=0.01)$. As a consequence, vitamin D deficiency was found to be correlated with the presence of antithyroid antibodies $(p=0.01)$ [31]. Choi et al. observed in a crosssectional study that serum $25(\mathrm{OH}) \mathrm{D}$ levels were significantly lower in anti-TPO-positive (427/2793) compared to anti-TPOnegative $(2366 / 2793)$ female euthyroid subjects $(p=0.03)$ [32]. In a subgroup analysis of pre- $(n=908)$ and postmenopausal $(n=1885)$ women, the serum $25(\mathrm{OH}) \mathrm{D}$ levels were significantly lower in pre-menopausal women with anti-TPO antibodies $(p=0.049)$ but not in postmenopausal women with these antibodies ( $p=0.186$ ) [32]. Also, Goswami et al. found a significant inverse correlation between serum vitamin D levels and antiTPO positivity $(p=0.04)$ in an Asian Indian population [33]. Arslan et al. found anti-TPO positivity more frequently observed in healthy volunteers with severe $(<10 \mathrm{ng} / \mathrm{mL})$ and moderate

Table 3 Autoantibodies detected in $23^{\mathrm{b}}$ patients with ASIA in relation to SIIS

\begin{tabular}{ll}
\hline Autoantibodies & No. of patients \\
\hline ANA/ENA & a \\
Anti-CL & 6 \\
ANCA & 7 \\
IgM-RF & 4 \\
Anti-CCP & 4 \\
\hline
\end{tabular}

$A N A$ antinuclear antibodies, anti-dsDNA anti-double-stranded DNA antibodies, anti-SSA anti-Sjögren's syndrome-related antigen A, anti-SSB anti-Sjögren's syndrome-related antigen $\mathrm{B}$, anti-CENPB anti-centromere protein $\mathrm{B}$, anti-Scl-70 anti-topoisomerase I, anti-CL anti-cardiolipin, $A N C A$ anti-neutrophil cytoplasmic antibodies, $\operatorname{Ig} M-R F \operatorname{IgM}$ rheumatoid factor, anti-CCP anti-cyclic citrullinated peptide antibody

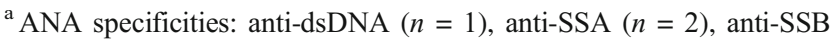
$(n=1)$, anti-CENP-B $(n=1)$, anti-Scl70 $(\mathrm{n}=1)$

${ }^{\mathrm{b}}$ One patient had two autoantibodies (anti-CCP and ANCA)
(10-20 ng/mL) vitamin D levels, compared to those with normal vitamin D levels ( $\geq 20 \mathrm{ng} / \mathrm{mL}$ ) [34]. Additionally, in antibodypositive patients, a significant inverse correlation between antiTPO and anti-TG titers and 25(OH)D levels $(p=0.017$ for antiTPO and $p=0.05$ for anti-TG) was found [34]. In a case-control study, Unal et al. found that anti-TG and anti-TPO titers were significantly higher in vitamin D-deficient AITD patients (183/ 281) than in vitamin D-sufficient AITD patients $(98 / 281)$ ( $p=0.02$ and $p=0.003$, respectively, for anti-TG and antiTPO) [35]. In this study, the 281 AITD patients consist of 254 patients with Hashimoto thyroiditis and 27 patients with Graves' disease. Several other studies also found a negative correlation between serum vitamin $\mathrm{D}$ levels and anti-thyroid antibody levels [36-40]. Mazokopakis et al. found that anti-TPO levels were significantly higher in vitamin D-deficient patients with Hashimoto's thyroiditis (HT) $(n=186)$ compared to HT patients with no vitamin D deficiency $(n=32)$ (364 \pm 181 vs. $115.8 \pm 37.1 \mathrm{IU} / \mathrm{mL}, p<0.0001$ ) [36], whereas Bozkurt et al. found that serum $25(\mathrm{OH}) \mathrm{D}$ levels were inversely correlated with anti-TPO $(p<0.001)$ and anti-TG levels $(p<0.001)$ in subjects with HT [36]. Furthermore, Bozkurt observed that serum 25(OH)D levels in HT patients were significantly lower than in healthy controls [37]. Shin et al. found that AITD patients (65 Hashimoto's thyroiditis and 46 Graves' disease) with antithyroid antibodies had lower levels of serum $25(\mathrm{OH}) \mathrm{D}$ than control patients without positive anti-thyroid antibodies $(12.6 \pm 5.5$ vs. $14.5 \pm 7.3 \mathrm{ng} / \mathrm{mL}$, respectively, $p<0.001$ ) [38]. They also found that $25(\mathrm{OH}) \mathrm{D}$ levels were inversely correlated with the anti-TPO levels $(p<0.001)$ in the HT and Graves' patients. More recently, Wang et al. analyzed a total of 1714 Chinese healthy adults and reported that subjects that tested positive for anti-TG $(n=315)$ had lower serum $25(\mathrm{OH}) \mathrm{D}$ levels compared to subjects who were anti-TG negative $(p<0.01)$ [39]. Furthermore, they observed that higher anti-TG titers were associated with lower $25(\mathrm{OH}) \mathrm{D}$ levels independent of age, ethnicity, 
and TSH levels in females but not in males $(p=0.014)$. Finally, in non-lactating women with postpartum thyroiditis, anti-TPO and anti-TG titers were found to be inversely correlated with vitamin D levels $(p<0.001)$ [40].

In contrast, D'Aurizio et al. did not observe statistically significant differences in vitamin D levels between healthy controls and either patients with HT and/or Graves' disease $(n=100)$ and anti-TPO and/or anti-TSH receptor autoantibody positivity [41]. Also, Ma et al. did not find serum $25(\mathrm{OH}) \mathrm{D}$ levels to be associated with anti-TPO or anti-TG levels in 70 patients with newly diagnosed HT [42]. However, an association between serum 25(OH)D levels and anti-TSH receptor autoantibody levels was observed in their 70 patients $(p=0.036)$ [42]. Yasuda et al. evaluated 26 female patients with newly onset Graves' disease and found no association between serum $25(\mathrm{OH}) \mathrm{D}$ levels and anti-TSH receptor autoantibody levels [43]. In women with polycystic ovary syndrome and positive anti-TPO and/or anti-TG antibody levels, no correlation between $25(\mathrm{OH}) \mathrm{D}$ levels and these antibodies was seen [44]. Finally, Effraimidis et al. reported a longitudinal study with a 5-year follow-up period in which serum $25(\mathrm{OH}) \mathrm{D}$ levels of 521 euthyroid subjects were analyzed and related to the occurrence of thyroid peroxidase antibodies (anti-TPO) [45]. Subjects were euthyroid women who had first- or second-degree relatives with overt AITD who had normal TSH and no thyroid antibodies at baseline. Subjects that developed anti-TPO within a period of 5 years were compared to subjects who remained anti-TPO negative, matched for age, BMI, smoking status, estrogen use, month of blood sampling, and duration of follow-up [45]. Sixty-seven subjects became positive for anti-TPO during follow-up, without developing abnormal TSH. No association with serum $25(\mathrm{OH}) \mathrm{D}$ levels was reported.

In conclusion, several studies suggested an association between the presence of anti-TPO and/or anti-TG and vitamin D levels and/or between autoantibody level and vitamin D level (Table 4). In a prospective study, however, vitamin D levels were not found to be a risk factor for the development of antiTPO.

\section{Connective tissue diseases}

Low levels of vitamin D are often found in systemic lupus erythematosus (SLE) patients [46, 47]. Vitamin D levels are lower in postmenopausal SLE patients $(n=80)$ compared to pre-menopausal SLE patients $(n=80)(p=0.02)$ [48]. No association, however, could be observed between vitamin D food intake and supplements and risk of the development of SLE [49]. ANA-positive SLE patients are more likely to have vitamin D deficiency $(\leq 20 \mathrm{ng} / \mathrm{mL})$ compared to ANAnegative SLE controls $(p=0.011)$ [46]. Also, anti-dsDNA autoantibody levels increased from normal vitamin D concentrations, to insufficient vitamin D levels and from insufficient to vitamin D-deficient patient subsets as found in 177 Hungarian SLE patients $(p=0.021)$ [48]. In women with newly diagnosed SLE, Bonakdar et al. also found higher titers of anti-dsDNA antibodies with more severe vitamin D deficiency $(p<0.001)$ [50]. Also, Mok et al. showed a significant negative correlation between $25(\mathrm{OH}) \mathrm{D}$ levels and antidsDNA levels $(p=0.02)$ or anti-C1q levels $(p=0.02)$ in their SLE patients $(n=290)$ [51]. In contrast, Thudi et al. found higher levels of anti-dsDNA in a small group of female lupus patients with levels of vitamin $\mathrm{D}$ that were greater than $47.7 \mathrm{nmol} / \mathrm{L}$ compared to subjects with $25(\mathrm{OH}) \mathrm{D}$ levels lower than $47.7 \mathrm{nmol} / \mathrm{L}(p=0.0069)(n=37)$ [52]. Finally, in a small study performed in 28 Saudi children with SLE, levels of $25(\mathrm{OH}) \mathrm{D}$ tended to be inversely correlated with anti-dsDNA titers and ANA [53].

Also, in other connective tissue diseases, low levels of vitamin D are found to be correlated with autoantibodies. In patients with Sjögren's syndrome, an inverse correlation between the concentrations of $25(\mathrm{OH}) \mathrm{D}$ and the titers of $\operatorname{IgM}$ rheumatoid factor were found $(n=25)$ [54]. In patients with mixed connective tissue disease (MCTD), higher serum levels of anti-U1-RNP (anti-ribonucleoprotein) antibodies were found in patients with low vitamin D levels $(p=0.022)$ [55]. Also, in 161 undifferentiated connective tissue disease (UCTD) patients, autoantibody profiles showed that serum levels of anti-U1-RNP, anti-SSA, and anti-CCP antibodies were inversely correlated to vitamin D levels $(p<0.05)$ [56]. During an average follow-up period of 2.3 years, $35 / 161$ patients developed an established connective tissue disease. Vitamin D levels were lower in these patients compared to the vitamin D levels as found in the 126/161 UCTD patients that did not develop an established CTD (14.7 \pm 6.45 vs. $33.0 \pm 13.4 \mathrm{ng} / \mathrm{mL}, p=0.0001$ ) [56]. In a cross-sectional study in 23 pre-menopausal women with primary anti-phospholipid syndrome (APS), serum vitamin D levels and IgG and IgM anti-cardiolipin (anti-CL) antibodies were investigated and compared to vitamin $\mathrm{D}$ levels in 23 age- and race-matched healthy controls [57]. Lower serum levels of 25(OH)D [21.64 mg/dL (11.26) vs. $28.59 \mathrm{mg} / \mathrm{dL}$ (10.67), $p=0.039]$ were found in the APS patients when compared to controls. No correlation, however, was found between vitamin D levels and IgG anti-CL levels ( $p=0.222)$ and/or IgM anti-CL levels $(p=0.535)$. In a large multinational study in patients with systemic sclerosis ( $\mathrm{SSc}$ ), vitamin D concentrations and the presence of anti-nuclear antibodies (ANA), anti-SCL70 antibodies, and RF were determined [58]. Three hundred twentyseven serum samples of European patients with SSc and 141 samples of healthy controls were studied. Patients with SSc had significantly lower serum vitamin D concentrations compared to healthy controls $(p<0.001)$. An inverse relation between RF positivity and the vitamin D concentration was found $(p<0.001)$. No association was found between vitamin D levels and the presence of ANA and/or anti-SCL70. 
Table 4 Studies in which vitamin D levels are correlated to thyroid autoantibodies in thyroid autoimmune diseases (AITDs)

\begin{tabular}{|c|c|c|c|c|c|c|c|}
\hline Author & Year & Country & Subjects & Vitamin D (ng/ml) & $\begin{array}{l}\text { Thyroid } \\
\text { autoantibodies }\end{array}$ & $P$ value ${ }^{*}$ & Reference \\
\hline Kivity S. et al. & 2011 & Hungary & $\begin{array}{l}92 \text { thyroid diseases }^{\mathrm{a}} \text { ( } 28 \mathrm{HT}, 22 \\
\text { GD, } 42 \text { negative } \mathrm{Ab} \text { ), } 98 \mathrm{CTRL}\end{array}$ & NR & $\begin{array}{l}\text { anti-TPO, } \\
\text { anti-TG }\end{array}$ & 0.01 & {$[31]$} \\
\hline Choi Y.M. et al. & 2014 & Korea & $\begin{array}{l}427 \text { TPOAb }+ \\
2366 \text { TPOAb - (CTRL) }\end{array}$ & $\begin{array}{l}22.0 \pm 0.6 \text { vs. } \\
23.5 \pm 0.3\end{array}$ & anti-TPO & 0.03 & {$[32]$} \\
\hline Goswami et al. & 2009 & India & $\begin{array}{l}642(559 \text { vit. } \mathrm{D} \leq 25 \mathrm{nmol} / \mathrm{l} \\
83 \text { vit. } \mathrm{D}>25.0 \mathrm{nmol} / \mathrm{l})\end{array}$ & $\begin{array}{l}14.5 \pm 3.5 \text { vs. } \\
37.5 \pm 16.3\end{array}$ & anti-TPO & $0.04^{\dagger}$ & {$[33]$} \\
\hline Arslan M.S. et al. & 2015 & Turkey & $\begin{array}{l}155 \text { volunteers }\left(53 \text { group } 1^{\mathrm{f}}, 61\right. \\
\left.\text { group } 2^{\mathrm{g}}, 41 \text { group } 3^{\mathrm{h}}\right)\end{array}$ & $\begin{array}{l}<10 \text { vs. } \\
10-19.9 \text { vs. } \geq 20\end{array}$ & $\begin{array}{l}\text { anti-TPO, } \\
\text { anti-TG }\end{array}$ & $\begin{array}{l}0.017 \\
0.05\end{array}$ & {$[34]$} \\
\hline Unal A.D. et al. & 2014 & Turkey & 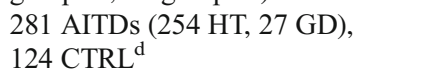 & $\begin{array}{l}13.4 \pm 3.6 \text { vs. } \\
29.5 \pm 10\end{array}$ & $\begin{array}{l}\text { anti-TPO, } \\
\text { anti-TG }\end{array}$ & $\begin{array}{l}0.003 \\
0.02\end{array}$ & {$[35]$} \\
\hline Mazokopakis et al. & 2015 & Greece & $\begin{array}{l}218 \text { HT (186 vit. D deficiency, } \\
32 \text { vit. D sufficiency) }\end{array}$ & $14.6 \pm 7.2$ & $\begin{array}{l}\text { anti-TPO, } \\
\text { anti-TG }\end{array}$ & $\begin{array}{l}<0.00001 \\
\text { NS }\end{array}$ & {$[36]$} \\
\hline Bozkurt N. et al. & 2013 & Turkey & $\begin{array}{l}\left.360 \text { AITDs ( } 180 \mathrm{HT}, 180 \mathrm{HT}^{\mathrm{i}}\right) \text {, } \\
180 \text { CTRL }\end{array}$ & $\begin{array}{l}11.4 \pm 5.2 \text { vs. } \\
13.1 \pm 5.9 \text { vs. } \\
5.4 \pm 6.8\end{array}$ & $\begin{array}{l}\text { anti-TPO, } \\
\text { anti-TG }\end{array}$ & $\begin{array}{l}<0.001 \\
<0.001\end{array}$ & {$[37]$} \\
\hline Shin D.Y. et al. & 2014 & Korea & $\begin{array}{l}111 \text { AITDs, } \\
193 \text { non-AITDs }\end{array}$ & $\begin{array}{l}12.6 \pm 5.5 \text { vs. } \\
14.5 \pm 7.3\end{array}$ & anti-TPO & $<0.001$ & {$[38]$} \\
\hline Wang X. et al. & 2015 & China & $\begin{array}{l}1714 \text { Chinese adults ( } 1197 \\
\text { females, } 517 \text { males) }\end{array}$ & $13.61(10.05-18.47)$ & $\begin{array}{l}\text { anti-TG } \\
\text { anti-TG titers }\end{array}$ & $\begin{array}{l}<0.01 \\
0.014\end{array}$ & [39] \\
\hline Krysiak R. et al. & 2016 & Poland & $\begin{array}{l}38 \mathrm{PPT}^{\mathrm{k}} \\
21 \mathrm{CTRL}^{1}\end{array}$ & $\begin{array}{l}25.0 \pm 10 \text { vs. } \\
40.0 \pm 12\end{array}$ & $\begin{array}{l}\text { anti-TPO, } \\
\text { anti-TG }\end{array}$ & $\begin{array}{l}<0.001 \\
<0.001\end{array}$ & {$[40]$} \\
\hline D'Aurizio F. et al. & 2015 & Italy & $\begin{array}{l}100 \text { AITDs ( } 52 \mathrm{HT}, 48 \mathrm{GD}) \text {, } \\
126 \text { CTRL }\end{array}$ & $\begin{array}{l}25.8 \text { vs. } \\
30\end{array}$ & anti-TPO & NS & {$[41]$} \\
\hline Ma J. et al. & 2015 & China & $\begin{array}{l}140 \text { AITDs (70 HT, } 70 \text { GD), } \\
70 \text { CTRL }^{\mathrm{e}}\end{array}$ & $\begin{array}{l}31.00-31.71 \mathrm{vs} \\
1.33\end{array}$ & $\begin{array}{l}\text { anti-TPO, } \\
\text { anti-TG }\end{array}$ & NS & {$[42]$} \\
\hline Yasuda T. et al. & 2012 & Japan & $\begin{array}{l}26 \mathrm{GD} \\
46 \mathrm{CTRL}^{\mathrm{j}}\end{array}$ & $\begin{array}{l}14.4 \pm 4.9 \\
17.1 \pm 4.1\end{array}$ & $\begin{array}{l}\text { anti-TPO, } \\
\text { anti-TG }\end{array}$ & NR & {$[43]$} \\
\hline Muscogiuri G. et al. & 2015 & Italy & $\begin{array}{l}50 \text { PCOS (12 TPOAb/TGAb +), } \\
38 \text { TPOAb/TGAb -) }\end{array}$ & $32.0 \pm 22.6,49.6 \pm 19.9$ & $\begin{array}{l}\text { anti-TPO, } \\
\text { anti-TG }\end{array}$ & $\begin{array}{l}0.21 \\
0.16\end{array}$ & {$[44]$} \\
\hline Effraimidis G. et al. & 2012 & Netherlands & $\begin{array}{l}67 \mathrm{AITDs}^{\mathrm{b}} \\
67 \mathrm{CTRL}^{\mathrm{c}}\end{array}$ & $\begin{array}{l}21.6 \pm 9.2 \text { vs. } \\
21.2 \pm 9.3\end{array}$ & anti-TPO & NS & [45] \\
\hline
\end{tabular}

AITDs = Autoimmune Thyroid Diseases; HT = Hashimoto's thyroiditis; GD = Graves' disease; CTRL = Controls; NR = Not reported; anti-TPO = Antithyroid peroxidase; anti-TG = anti-thyroglobulin antibodies; PCOS = Polycystic Ovary Syndrome.

* Correlation between vitamin D levels and positive thyroid antibodies

${ }^{\dagger}$ Controlled for age

a 58 vitamin D deficiency $(<10 \mathrm{ng} / \mathrm{ml}), 34$ vitamin $\mathrm{D}>10 \mathrm{ng} / \mathrm{ml}$

${ }^{\mathrm{b}}$ anti-TPO negative at baseline (cases)

${ }^{\mathrm{c}}$ anti-TPO negative (controls)

d age matched healthy controls

${ }^{\mathrm{e}}$ matched for sex, age, and smoking status with the GD patients

${ }^{\mathrm{f}}$ Vitamin D level $<10 \mathrm{ng} / \mathrm{ml}$

${ }^{\mathrm{g}}$ Vitamin D level 10-19.9 ng/ml

${ }^{\mathrm{h}}$ Vitamin D level $\geq 20 \mathrm{ng} / \mathrm{ml}$

${ }^{\mathrm{i}}$ sex-, age-, and body mass index (BMI)-matched euthyroid subjects with newly diagnosed HT

${ }^{\mathrm{j}}$ healthy female subjects

${ }^{\mathrm{k}}$ non-lacting L-thyroxine-treated women with postpartum thyroiditis (PPT)

${ }^{1}$ matched healthy postpartum women

In conclusion, an inverse correlation between vitamin $\mathrm{D}$ levels and the presence of autoantibodies in connective tissue diseases has been described (Table 5). In several studies, vitamin D deficiency was found to be inversely correlated with autoantibody titers in connective tissue diseases, although findings are at present not conclusive.

\section{Inflammatory arthritides}

In the Women's Iowa Health Study, i.e., a prospective cohort of 29,368 women, it was demonstrated that vitamin D food intake was inversely associated with the risk to develop rheumatoid arthritis (RA) $(n=152)$ [59]. However, in smaller 
Table 5 Studies in which vitamin D levels are correlated to CTD autoantibodies in connective tissue diseases (CTDs)

\begin{tabular}{|c|c|c|c|c|c|c|c|}
\hline Author & Year & Country & Subjects & $\begin{array}{l}\text { Vitamin D } \\
(\mathrm{ng} / \mathrm{ml})\end{array}$ & $\begin{array}{l}\text { Positive CTD } \\
\text { autoantibodies }\end{array}$ & $P$ value $^{\mathrm{h}}$ & Reference \\
\hline Ritterhouse L. et al. & 2011 & USA & $\begin{array}{l}32 \text { SLE, } \\
32 \text { CTRL }^{\mathrm{a}}\end{array}$ & $\begin{array}{l}17.3 \text { vs. } \\
17.4^{\wedge} \text { vs. } 29.4^{\wedge}\end{array}$ & ANA & $<0.01$ & {$[46]$} \\
\hline Szodoray P. et al. & 2011 & Hungary & $\begin{array}{l}177 \text { SLE ( } 160 \\
\text { females, } 17 \text { males) }\end{array}$ & $\begin{array}{l}<15 \text { vs. } 15-30 \\
\text { vs. } \geq 30\end{array}$ & anti-dsDNA & 0.021 & {$[48]$} \\
\hline Costenbader K.H. et al. & 2008 & $\begin{array}{r}\text { Boston, } \\
\text { USA }\end{array}$ & $190 \mathrm{SLE}$ & NR & Risk of SLE & NS & [49] \\
\hline Bonakdar Z.S. et al. & 2011 & Iran & $40 \mathrm{SLE}^{\mathrm{b}}$ & $\begin{array}{l}25-39.9 \text { vs. } \\
12.5-24.9 \text { vs. } \\
<12.5 \mathrm{nmol} / 1\end{array}$ & anti-dsDNA & $<0.001$ & {$[50]$} \\
\hline Mok C.C. et al. & 2012 & China & $290 \mathrm{SLE}^{\mathrm{c}}$ & $<30$ vs. $<15$ & $\begin{array}{l}\text { anti-dsDNA, } \\
\text { anti-C1q }\end{array}$ & $\begin{array}{l}0.02 \\
0.02\end{array}$ & {$[51]$} \\
\hline Thudi A. et al. & 2008 & Texas, USA & $37 \mathrm{SLE}$ & $\begin{array}{l}>47 \mathrm{nmol} / 1 \mathrm{vs} . \\
<47 \mathrm{nmol} / 1\end{array}$ & anti-dsDNA & 0.0069 & {$[52]$} \\
\hline AlSaleem A. et al. & 2015 & Saudi Arabia & $\begin{array}{l}28 \text { SLE children ( } 26 \\
\text { female, } 2 \text { male) }\end{array}$ & $51.1 \pm 33.6$ & $\begin{array}{l}\text { anti-dsDNA, } \\
\text { ANA }\end{array}$ & $\begin{array}{l}\text { NS } \\
\text { NS }\end{array}$ & {$[53]$} \\
\hline Muller K. et al. & 1990 & Denmark & 35 Sjogren & $28.2 \pm 12.4$ & $\begin{array}{l}\text { IgM RF, } \\
\text { IgA RF }\end{array}$ & $\begin{array}{l}<0.05 \\
\text { NS }\end{array}$ & {$[54]$} \\
\hline Hajas A. et al. & 2015 & Hungary & $\begin{array}{l}125 \mathrm{MCTD} \\
48 \mathrm{CTRL}^{\mathrm{d}}\end{array}$ & $26.16 \pm 13.5$ & $\begin{array}{l}\text { anti-U1-RNP, } \\
\text { anti-CL IgA }\end{array}$ & $\begin{array}{l}0.022 \\
0.015\end{array}$ & {$[55]$} \\
\hline Zold E. et al. & 2008 & Hungary & $161 \mathrm{UCTD}$ & $\begin{array}{l}\text { NR; } \\
\quad \text { hypovitaminosis D }\end{array}$ & $\begin{array}{l}\text { anti-U1-RNP, } \\
\text { anti-SSA, } \\
\text { anti-CCP }\end{array}$ & $\begin{array}{l}0.024 \\
0.029 \\
0.0001\end{array}$ & {$[56]$} \\
\hline Paupitz J.A. et al. & 2010 & Brazil & $\begin{array}{l}23 \mathrm{APS}^{\mathrm{e}} \\
23 \mathrm{CTRL}^{\mathrm{f}}\end{array}$ & $\begin{array}{l}21.64 \pm 11.26 \mathrm{vs} . \\
28.59 \pm 10.67 \mathrm{mg} / \mathrm{dl}\end{array}$ & $\begin{array}{l}\text { IgG anti-CL } \\
\text { IgM anti-CL }\end{array}$ & $\begin{array}{l}0.222 \\
0.535\end{array}$ & {$[57]$} \\
\hline Arnson Y. et al. & 2011 & Israel & $\begin{array}{l}327 \mathrm{SSc} \\
141 \mathrm{CTRL}^{\mathrm{g}}\end{array}$ & $\begin{array}{l}18.2 \pm 13.2 \\
12.7 \pm 6.6 \\
16.8 \pm 12.3\end{array}$ & $\begin{array}{l}\text { ANA, } \\
\text { Anti-SCL 70, } \\
\text { RF }\end{array}$ & $\begin{array}{l}\text { NS } \\
\text { NS } \\
<0.001\end{array}$ & {$[58]$} \\
\hline
\end{tabular}

SLE = Systemic lupus erythematosus; ANA = Antinuclear antibodies; anti-dsDNA = Anti-double stranded DNA antibodies; APS = Antiphospholipid syndrome; PV = Pemphigus vulgaris; IgM RF = IgM rheumatoid factor; IgA RF = IgA rheumatoid factor; anti-CL IgA = anti-cardiolipin IgA; RNP = ribonucleoprotein; anti-SSA = anti-Sjögren's-syndrome-related antigen A; anti-CCP = Anti-cyclic citrullinated peptide antibody; SSc = Systemic sclerosis; anti-SCL70 = anti-topoisomerase I; RF = Rheumatoid factor

${ }^{a}$ Healthy matched controls; $n=14$ ANA-positive,$n=18$ ANA-negative ${ }^{\wedge}$

${ }^{\mathrm{b}} 5$ mild vitamin D deficiency, 25 moderate vitamin D deficiency, 7 severe vitamin D deficiency

c 277 vitamin D insufficiency ( $<30 \mathrm{ng} / \mathrm{ml}), 77$ vitamin D deficiency $(<10 \mathrm{ng} / \mathrm{ml})$

d age- and sex-matched healthy controls

${ }^{e}$ pre-menopausal women

f age- and race-matched healthy controls

${ }^{\mathrm{g}}$ healthy controls

${ }^{\mathrm{h}}$ Correlation between vitamin D levels and positive CTD antibodies

studies, no association was found. Firstly, in 722 patients with RA from the Nurses' Health Study and Nurses' Health Study II [49], and secondly, in the study by Nielen et al. $(n=79)$, no association between vitamin D deficiency and later development of RA was observed [60]. Feser et al. found in a healthy population at increased risk for RA that $25(\mathrm{OH}) \mathrm{D}$ levels were not associated with the presence of RA-related autoantibodies (76 subjects being positive for anti-CCP and/or RF) $(P=0.15)$ [61]. In contrast, RA patients with severe vitamin D deficiency (serum levels $\leq 15 \mathrm{nmol} / \mathrm{L})(n=15)$ were shown to test more frequently positive for RF (100\%) when compared to RA patients with normal vitamin D serum levels $(n=200)$ $(77.5 \%)(p=0.05)$ [62]. In a 10-year prospective cohort study of 775 RA, 738 ankylosing spondylitis (SPA), and 721 psoriatic arthritis (PsA) patients, 25(OH)D levels, RF, and anticyclic citrullinated peptide (anti-CCP) antibodies were measured [63]. Levels were compared to 677 subjects without inflammatory rheumatic diseases. Five hundred twenty-eight RA patients $(68.1 \%)$ were found to be RF positive and 482 RA patients $(62.2 \%)$ anti-CCP positive. The prevalence of antiCCP positivity was significantly higher in the $25(\mathrm{OH}) \mathrm{D}$ deficiency group $(<20 \mathrm{ng} / \mathrm{mL})(p<0.022)$ compared to patients with sufficient levels of vitamin D [63]. Subclinical gut inflammation may be present in patients with SPA. In a cross-sectional study by Teichman et al., 47/76 patients with SPA tested positive for human anti-tissue-transglutaminase-IgA (htTG) 
antibodies. These patients had significant lower 25(OH)D levels compared to SPA patients that tested negative for antihtTG antibodies (mean 17.4 vs. mean $41.5 \mathrm{ng} / \mathrm{mL} ; p<0.005$ ) [64].

In conclusion, the relation between vitamin $\mathrm{D}$ food intake and the risk of development of RA later in life is controversial. Furthermore, some studies suggest that there is an inverse correlation between vitamin D levels and the presence of RA-related autoantibodies (RF and/or anti-CCP) in patients with RA (Table 6) and/or anti-TTG antibodies in SPA.

\section{Multiple sclerosis}

Low levels of vitamin D are common in patients with multiple sclerosis (MS) and are associated with more severe disability and an increased risk for relapses of the disease [65]. Also, the geographical distribution of MS suggests that people living in areas were vitamin D levels are low are more prone to develop MS. Furthermore, vitamin D supplementation may correct immunological abnormalities that are observed in MS [66, 67]. As a consequence, vitamin D supplementation is currently being studied for the prevention of disease relapses [68]. An association between low vitamin D levels and MSrelated antibodies are, however, rarely reported. In a cross-sectional study of pediatric-onset MS, vitamin D status was found to be related to antibody levels to cytomegalovirus (CMV), while antibodies to other viruses (Epstein-Barr virus, herpes simplex virus 1 or 2) were not found to be associated with vitamin D levels [69]. Epstein-Barr virus (EBV) is postulated to play an important role in the pathogenesis of MS by infecting B cells [70]. Importantly, antibodies against the EBV antigens are associated with an increased risk of developing MS later in life [71]. Salzer et al. showed an inverse association between vitamin D levels and antibody titers against EBV in MS patients [72]. Décard et al. investigated serum 25(OH)D levels and EBV immunoreactivity in 25 individuals who donated blood prior to the first clinical MS manifestation [73]. Cross-sectional analyses revealed a gradual decrease of vitamin D levels and increase of anti-EBNA-1 IgG titers before the first clinical manifestation of MS. Furthermore, Disanto et al. showed decreased anti-EBNA-1 IgG levels after 12 weeks of vitamin D supplementation in 15 relapsing-remitting MS (RRMS) patients $(p=0.016)$ [74]. Another study by Najafipoor et al. examined the effect of vitamin D supplementation for 6 months on the anti-VCA IgG and anti-EBNA-1 IgG levels in 40 RRMS patients [75]. They found six patients $(15 \%)$ with a decline in the level of anti-VCA titers and six patients $(15 \%)$ with a reduction in anti-EBNA1 titers in the supplemented group. There was, however, no significant relationship between the vitamin $\mathrm{D}$ levels and antibody levels (VCA IgG $p=0.420$; EBNA1 IgG $p=0.853)$.

Table 6 Studies in which vitamin D levels are correlated to autoantibodies associated with inflammatory arthritides

\begin{tabular}{|c|c|c|c|c|c|c|c|}
\hline Author & Year & Country & Subjects & $\begin{array}{l}\text { Vitamin D } \\
(\mathrm{ng} / \mathrm{ml})\end{array}$ & $\begin{array}{l}\text { Vitamin D effect / } \\
\text { Autoantibodies }\end{array}$ & $P$ value $^{\mathrm{d}}$ & Reference \\
\hline Merlino L.A. et al. & 2004 & USA & $\begin{array}{l}152 \mathrm{RA}+, 29.368 \\
\text { RA - }\end{array}$ & NR & $\begin{array}{l}\text { Risk of RA } \\
\text { (RR 0.67) }\end{array}$ & 0.05 & {$[59]$} \\
\hline Nielen N.M. et al. & 2006 & The Netherlands & $\begin{array}{l}79 \text { RA, } \\
79 \text { CTRL }^{\mathrm{a}}\end{array}$ & $<20 \mathrm{nmol} / \mathrm{l}$ & Risk of RA & NS & {$[60]$} \\
\hline Costenbader K.H. et al. & 2008 & Boston, USA & $722 \mathrm{RA}$ & NR & Risk of RA & NS & [49] \\
\hline Feser M. et al. & 2009 & USA & $\begin{array}{l}79 \text { RA, } \\
154 \text { CTRL }^{\text {b }}\end{array}$ & $\begin{array}{l}26.89 \pm 10.04 \text { vs. } \\
25.30 \pm 9.01\end{array}$ & $\begin{array}{l}\text { Anti-CCP } \\
\text { and/or RF }\end{array}$ & 0.15 & {$[61]$} \\
\hline Haga H.J. et al. & 2013 & Denmark & $302 \mathrm{RA}$ & $\leq 15 \mathrm{nmol} / 1$ & $\mathrm{RF}$ & $0.05^{\dagger}$ & {$[62]$} \\
\hline Urruticoechea-Arana et al. & 2015 & Spain & $\begin{array}{l}775 \text { RA, } 738 \text { SPA } \\
\text { and } 721 \text { PsA, } 677 \\
\text { CTRL }^{\mathrm{c}}\end{array}$ & $<20 \mathrm{ng} / \mathrm{ml}$ & $\begin{array}{l}\text { RF, } \\
\text { Anti-CCP }\end{array}$ & 0.022 & {$[63]$} \\
\hline Teichman J. et al. & 2010 & Germany & $\begin{array}{l}76 \text { SPA, } \\
116 \text { PsA }\end{array}$ & $\begin{array}{l}17.4 \pm 13.19 \text { vs. } \\
41.5 \pm 44.21\end{array}$ & htTG & $<0.005$ & {$[64]$} \\
\hline
\end{tabular}

$\mathrm{NR}=$ not relevant; $\mathrm{RR}=$ Relative Risk; $\mathrm{NR}=$ Not reported $\mathrm{RA}=$ Rheumatoid Arthritis SLE = Systemic lupus erythematosus, anti-CCP = Anti-cyclic citrullinated peptide antibody; SPA = Ankylosing Spondylitis

${ }^{a}$ healthy blood donors matched for age, sex, and time of donation

b autoantibody-negative controls

${ }^{\mathrm{c}}$ non-CIRD (chronic inflammatory rheumatic diseases) subjects

${ }^{\mathrm{d}}$ Correlation between vitamin $\mathrm{D}$ levels and positive inflammatory arthritides antibodies

${ }^{e}$ compared vitamin $\mathrm{D} \leq 15 \mathrm{nmol} / \mathrm{l}(\mathrm{n}=15)$ to normal vitamin $\mathrm{D}$ levels $(\mathrm{n}=200)$ 
In summary, both vitamin D levels and autoantibodies against EBV are reported to be important in the pathogenesis of MS. A causal relation between these two etiological factors is suggested in several studies (Table 7).

\section{Other studies}

Inflammatory bowel disease (IBD) is another disease that is linked to low vitamin D levels $[17,76]$. A prospective study by Santos-Antunes et al. found an inverse relationship between vitamin D levels and ANA positivity in IBD patients [77]. The presence of ANA has also been shown to correlate with low serum vitamin D levels in patients with leprosy $(p<0.001)$ [78]. Ritterhouse et al. observed that ANApositive healthy controls are significantly more likely to be deficient in vitamin D levels than ANA-negative healthy controls $(p=0.011)$ [46]. Nuti et al. found that 24 women with osteoporosis in the presence of coeliac disease and high levels of serum IgG anti-gliadin antibodies (IgG AGA) and tissue transglutaminase antibodies (anti-TTG) had lower serum 25(OH)D levels compared to 231 women with primary osteoporosis without coeliac disease $(p<0.01)$ [79]. They also found an inverse correlation between the serum 25(OH)D levels and the serum anti-TTG titers in these 24 women with primary osteoporosis and coeliac disease $(p<0.001)$. Karakan et al. investigated the presence of serum IgA anti-endomysial (IgA EMA) antibodies in relation to serum 25(OH)D levels in 135 patients with idiopathic osteoporosis and found that 13 patients $(9.6 \%)$ which tested positive for IgA EMA had lower serum $25(\mathrm{OH}) \mathrm{D}$ levels compared to IgA EMA-negative patients $(p<0.01)$ [80]. However, none of these 13 patients had findings consistent with coeliac disease. Furthermore, in a cross-sectional study by Ota et al. of 133 women with recurrent pregnancy losses, a significantly higher prevalence of anti-phospholipid antibodies and TPO antibodies was found in 63 patients with low vitamin D levels $(<30 \mathrm{ng} / \mathrm{mL})$ compared to 70 patients with normal vitamin D levels $(p<0.05$ each) [81]. A prospective study by Njemini et al. investigated the prevalence of several organ-specific and non-organspecific autoantibodies and serum 25(OH)D levels in 152 unselected Cameroonians [82]. No association between the presence of autoantibodies and serum 25(OH)D levels could be found in this African population. Finally, Carvalho et al. observed anti-vitamin D antibodies in a subset of patients with several different autoimmune diseases [83], but could not find a significant difference in serum 25(OH)D levels between the anti-vitamin D antibody-positive $(n=7)$ and anti-vitamin Dnegative $(n=164)$ patients.

In conclusion, an inverse correlation between serum vitamin D levels and the presence of autoantibodies in several other conditions has been suggested as well (Table 8).

\section{Discussion}

The aim of our study was to investigate the relation between vitamin D levels in patients with ASIA in relation to silicone implant incompatibility and the presence of autoantibodies. Vitamin D deficiency or insufficiency was found to be related to the presence of autoantibodies in our patients with silicone breast implants. A critical limitation to this finding is that we did not perform a study in control patients. Whether vitamin D deficiency is also related to the presence of autoantibodies in healthy control women remains therefore unknown.

Table 7 Studies in which vitamin D levels are correlated to autoantibodies associated with Multiple sclerosis (MS)

\begin{tabular}{|c|c|c|c|c|c|c|c|}
\hline Author & Year & Country & Subjects & $\begin{array}{l}\text { Vitamin D } \\
(\mathrm{ng} / \mathrm{ml})\end{array}$ & $\begin{array}{l}\text { Vitamin D effect / } \\
\text { Autoantibodies }\end{array}$ & $P$ value $^{\mathrm{d}}$ & Reference \\
\hline Mowry E.M. et al. & 2011 & USA & $\begin{array}{l}120 \mathrm{MS}^{\mathrm{a}} / \mathrm{CIS}, \\
20 \mathrm{CTRL}\end{array}$ & NR & $\begin{array}{l}\text { anti-CMV, } \\
\text { anti-EBV, HSV-1/-2 }\end{array}$ & $\begin{array}{l}0.004 \\
\mathrm{NS}\end{array}$ & [69] \\
\hline Salzer J. et al. & 2013 & Sweden & $\begin{array}{l}192 \mathrm{MS} \\
384 \mathrm{CTRL}\end{array}$ & NR & anti-EBNA1 & 0.03 & {$[72]$} \\
\hline Décard B.F.et al. & 2012 & Germany & $\begin{array}{l}25 \text { pre-CIS, } \\
25 \text { CTRL }^{\text {b }}\end{array}$ & NR & anti-EBNA1 & $<0.01$ & {$[73]$} \\
\hline Disanto G. et al. & 2013 & The Netherlands & $15 \mathrm{RRMS}^{\mathrm{c}}$ & NR & anti-EBNA1 & 0.016 & {$[74]$} \\
\hline Najafipoor A. et al. & 2015 & Iran & $\begin{array}{l}40 \text { RRMS (27 vit. D } \\
\text { suppl., } 13 \text { CTRL) }\end{array}$ & NR & $\begin{array}{l}\text { anti-VCA IgG, } \\
\text { anti-EBNA1 }\end{array}$ & $\begin{array}{l}0.420 \\
0.853\end{array}$ & {$[75]$} \\
\hline
\end{tabular}

$\mathrm{NR}=$ Not reported; CIS = clinically isolated syndrome (prior to first clinical MS manifestation); CMV = cytomegalovirus; EMB = Epstein Barr Virus; $\mathrm{HSV}=$

Herpes Simplex Virus; EBNA = Epstein-Barr Nuclear Antigen; RRMS = Relapsing remitting MS

${ }^{\text {a }}$ Pediatric-onset MS

${ }^{\mathrm{b}}$ age- and gender-matched healthy blood donors

${ }^{\mathrm{c}}$ vitamin D supplementation $(\mathrm{n}=27)$ and age- and gender-matched healthy blood donors

${ }^{\mathrm{d}}$ Correlation between vitamin $\mathrm{D}$ levels and positive antibodies 
Table 8 Studies in which vitamin D levels are correlated to antibodies in other autoimmune diseases

\begin{tabular}{|c|c|c|c|c|c|c|c|}
\hline Author & Year & Country & Subjects & $\begin{array}{l}\text { Vitamin D } \\
(\mathrm{ng} / \mathrm{ml})\end{array}$ & $\begin{array}{l}\text { Autoantibodies } \\
\text { (AAb) }\end{array}$ & $P$ value $^{\mathrm{d}}$ & Reference \\
\hline Santos-Antunos J. et al. & 2016 & USA & $68 \mathrm{IBD}(56 \mathrm{CD}, 12 \mathrm{UC})$ & $<4 \mathrm{ng} / \mathrm{ml}$ & ANA & $<0.05$ & {$[77]$} \\
\hline Ribeiro S.L.E. et al. & 2012 & Brazil & $\begin{array}{l}87 \text { Leprosy (22 ANA +, } \\
55 \text { ANA -) }\end{array}$ & $\begin{array}{l}31.20 \pm 10.8 \text { vs. } \\
53.03 \pm 24.99\end{array}$ & ANA & $<0.001$ & {$[78]$} \\
\hline Nuti R. et al. & 2001 & Italy & $\begin{array}{l}53^{\mathrm{a}} \mathrm{IgG} \text { AGA + }(24 \\
\mathrm{TG}-\mathrm{Ab}+, 29 \mathrm{TG}-\mathrm{Ab}-)\end{array}$ & $\begin{array}{l}17.8 \pm 7.2 \mathrm{vs} . \\
55.1 \pm 20.3 \mathrm{nmol} / 1\end{array}$ & $\begin{array}{l}\text { IgG AGA, } \\
\text { Anti-TG }\end{array}$ & $<0.01$ & [79] \\
\hline Karakan T. et al. & 2007 & Turkey & $\begin{array}{l}135 \text { low } \text { BMD }^{\mathrm{b}}(13 \\
\text { EMA +, } 122 \text { EMA -) }\end{array}$ & $11.6 \pm 1.89$ vs. & IgA EMA & $<0.01$ & {$[80]$} \\
\hline Ota K. et al. & 2014 & USA & $\begin{array}{l}133 \text { RPL ( } 63 \text { vit D. def., } \\
70 \text { normal vit. D) }\end{array}$ & $\begin{array}{l}19.8 \pm 4.88 \\
<30 \mathrm{ng} / \mathrm{ml} \text { vs. }\end{array}$ & $\begin{array}{l}\mathrm{APA}^{\mathrm{c}}, \text { ANA, anti- } \\
\text { ssDNA, anti-TPO }\end{array}$ & $<0.05$ & {$[81]$} \\
\hline Njemini R. et al. & 2002 & Belgium & 152 Cameroonians & $\begin{array}{l}\geq 30 \mathrm{ng} / \mathrm{ml} \\
12.5 \pm 3.2 \mathrm{vs}\end{array}$ & Various $\mathrm{AAb}^{\mathrm{e}}$ & NS & {$[82]$} \\
\hline Carvalho J.F. et al. & 2007 & Israel & $\begin{array}{l}171 \text { SLE, } 56 \text { APS, } 18 \\
\text { PV, } 94 \text { CTRL }^{\mathrm{f}}\end{array}$ & $\begin{array}{l}21.1 \pm 7.7 \mathrm{mg} / 1 \\
28.4 \pm 9.6 \mathrm{vs} . \\
26.4 \pm 13.9\end{array}$ & anti-vitamin $\mathrm{D} \mathrm{Ab}$, & NS & [83] \\
\hline
\end{tabular}

IBD = Inflammamtory Bowel Disease; $\mathrm{CD}=$ Crohn's disease; UC = Ulcerative colitis; $\mathrm{BMD}=$ Bone mineral density; IgA EMA = IgA anti-endomysial; $\mathrm{RPL}=$ Recurrent pregnancy losses; $\mathrm{APS}=$ Antiphospholipid syndrome; APA = Antiphospholipid antibody

${ }^{\text {a }}$ Postmenopausal osteoporotic women

${ }^{\mathrm{b}}$ Idiopatic

${ }^{\mathrm{c}}$ Any IgG or IgM antibodies to phospholipids

${ }^{\mathrm{d}}$ Correlation between vitamin D levels and positive antibodies

${ }^{\mathrm{e}}$ Organ-specific and non-organ-specific autoantibodies

${ }^{\mathrm{f}}$ Comparing $\mathrm{n}=7$ anti-vitamin $\mathrm{D}$ positive and $\mathrm{n}=164$ anti-vitamin $\mathrm{D}$ negative

Furthermore, we reviewed the literature regarding an association between vitamin D deficiency and the development of autoantibodies in several other (autoimmune) diseases. To our knowledge, this link has not been reviewed before. Conflicting data regarding the relation between vitamin D levels and autoantibodies were found since low vitamin D levels were linked to the presence of autoantibodies and/or the antibody titers in some, but not all studies. Thirty-one studies described a significant negative correlation between serum vitamin D levels and autoantibodies: ten for antithyroid antibody levels [31-40], nine for autoantibodies in connective tissue diseases [46, 48, 50-52, 54-56, 58], two for RA-related autoantibodies (RF and/or anti-CCP) [62, 63], one for anti-TTG antibodies [64], four for autoantibodies against EBV in MS patients [69, 72-74], and five for autoantibodies in several other (autoimmune) diseases [77-81]. Thirteen studies could, however, not confirm this correlation [41-45, 49, 53, 57, 60-61, 75, 82-83].

Vitamin D deficiency has been underestimated for many years as a health problem. Importantly, the role of vitamin D insufficiency and/or deficiency in the development of different autoimmune diseases is at present increasingly studied [47, 84]. It has been demonstrated that many cells of the immune system express vitamin D receptors (VDRs), e.g., monocytes and dendritic cells (DC) [18]. Whereas resting $\mathrm{T}$ and $\mathrm{B}$ cells express negligible VDR, activation of these cells results in upregulation of VDR expression [19]. Furthermore, activated B cells express
CYP27B1 and CYP24A1 enzymes, which are responsible for the synthesis and breakdown of the active metabolite of vitamin $\mathrm{D}$, thereby regulating vitamin $\mathrm{D}$ activity in the microenvironment $[19,68,85]$. Importantly, Chen et al. demonstrated that $1,25(\mathrm{OH})_{2} \mathrm{D}$ has potent direct effects on $\mathrm{B}$ cell responses, inhibiting proliferation, generation of class-switched memory B cells, plasma cell differentiation, and Ig production [19]. Furthermore, they demonstrated that $1,25(\mathrm{OH})_{2} \mathrm{D}$ induced increased apoptosis of proliferating B cells [19]. Chen et al. therefore suggested that vitamin D deficiency could contribute to B cell hyperactivity, breakdown of B cell tolerance, and production of autoantibodies in SLE patients [19]. Subsequently, it was demonstrated in in vitro experiments that synthesis of $\mathrm{IgM}, \mathrm{IgG}$, and $\operatorname{IgA}$ by various stimuli was inhibited in the presence of $1,25(\mathrm{OH})_{2} \mathrm{D}$ [19]. These in vitro inhibitory effects of vitamin D are, however, not confirmed in vivo [86-88]. Ritterhouse et al. found that SLE patients with more pronounced B cell activation had lower mean 25(OH)D levels compared to SLE patients with less B cell activation [46]. Importantly, they also found that patients with vitamin D deficiency had higher mean serum IFN $\alpha$ activity than patients without a vitamin D deficiency [46]. IFN $\alpha$ is produced in large amounts by activated dendritic cells (DCs) and has multiple pro-inflammatory effects on autoreactive cells and is therefore considered to be a central player in the progression to and maintenance of autoimmunity [89]. Excessive dendritic cell activity could therefore be another hypothesis for the 
production of autoantibodies in vitamin D-deficient patients. Whether these pathophysiological hypotheses are relevant for the development of autoimmune diseases is, however, at present not clear.

\section{Conclusion}

Vitamin D may act as a regulatory agent of the immune system. Vitamin D deficiency is found to be related to the presence of autoantibodies in patients with silicone implant incompatibility syndrome. In line with our study, we found several reports that suggested that there is evidence that vitamin D levels are related to the presence and/or levels of autoantibodies in thyroid autoimmune diseases (AITDs), connective tissue diseases (CTDs), multiple sclerosis (MS), and several other (autoimmune) diseases. Randomized, controlled trials must be performed to elucidate whether vitamin D supplementation is beneficial as preventive therapy in patients with silicone breast implants to inhibit the development of autoantibodies.

\section{Compliance with ethical standards}

Funding sources None.

\section{Disclosures None.}

Open Access This article is distributed under the terms of the Creative Commons Attribution 4.0 International License (http:// creativecommons.org/licenses/by/4.0/), which permits unrestricted use, distribution, and reproduction in any medium, provided you give appropriate credit to the original author(s) and the source, provide a link to the Creative Commons license, and indicate if changes were made.

\section{References}

1. Colaris MJL, de Boer M, van der Hulst RR, Cohen Tervaert JW (2016) Two hundreds cases of ASIA syndrome following silicone implants - a comparative study of 30 years and a review of current literature. Immunol Res

2. Shoenfeld Y, Agmon-Levin N (2011) 'ASIA'-autoimmune /inflammatory syndrome induced by adjuvants. J Autoimmun 36: 4-8. doi:10.1016/j.jaut.2010.07.003

3. Cohen Tervaert JW, Kappel RM (2013) Silicone implant incompatibility syndrome (SIIS): a frequent cause of ASIA (Shoenfeld's syndrome). Immunol Res 56:293-298. doi:10.1007/s12026-013-8401-3

4. De Boer M, Colaris M, van der Hulst RR, Cohen Tervaert JW (2016) Is explantation of silicone breast implants useful in patients with complaints? Immunol Res

5. Janowsky EC, Kupper LL, Hulka BS (2000) Meta-analyses of the relation between silicone breast implants and the risk of connectivetissue diseases. N Engl J Med 342:781-790

6. Balk EM, Earley A, Avendano EA, Raman G (2016) Long-term health outcomes in women with silicone gel breast implants: a systematic review. Ann Intern Med 164:164-175. doi:10.7326/M15-1169
7. Shen GQ, Ojo-Amaize EA, Agopian MS, Peter JB (1996) Silicate antibodies in women with silicone breast implants: development of an assay for detection of humoral immunity. Clin Diagn Lab Immunol 3:162-166

8. Kossovsky N, Gornbein JA, Zeidler M, Stassi J, Chun G, Papasian N, Nguyen R, Ly K, Rajguru S (1995) Self-reported signs and symptoms in breast implant patients with novel antibodies to silicone surface associated antigens [anti-SSAA(x)]. J Appl Biomater 6:153-160

9. Zandman-Goddard G, Blank M, Ehrenfeld M, Gilburd B, Peter J, Shoenfeld Y (1999) A comparison of autoantibody production in asymptomatic and symptomatic women with silicone breast implants. J Rheumatol 26:73-77

10. Tenenbaum SA, Rice JC, Espinoza LR, Cuéllar ML, Plymale DR, Sander DM, Williamson LL, Haislip AM, Gluck OS, Tesser JR (1997) Use of antipolymer antibody assay in recipients of silicone breast implants. Lancet 349:449-454

11. Bar-Meir E, Teuber SS, Lin HC, Alosacie I, Goddard AG, Terybery J, Barka N, Shen B, Peter JB, Blank M et al (1995) Multiple antibodies in patients with silicone breast implants. J Autoimmun 8:267-277

12. Wolfram D, Oberreiter B, Mayerl C, Soelder E, Ulmer H, PizaKatzer H, Wick G, Backovic A (2008) Altered systemic serologic parameters in patients with silicone mammary implants. Immunol Lett 118:96-100. doi:10.1016/j.imlet.2008.03.007

13. Mithal A, Wahl DA, Bonjour JP, Burckhardt P, Dawson-Hughes B, Eisman JA et al (2009) Global vitamin D status and determinants of hypovitaminosis D. Osteoporos Int 20:1807-1820. doi:10.1007/ s00198-009-0954-6

14. Borella E, Nesher G, Israeli E, Shoenfeld Y (2014) Vitamin D: a new anti-infective agent? Ann N Y Acad Sci 1317:76-83. doi:10. 1111/nyas. 12321

15. Arnson Y, Amital H, Shoenfeld Y (2007) Vitamin D and autoimmunity: new aetiological and therapeutic considerations. Ann Rheum Dis 66:1137-1142

16. Rosen Y, Daich J, Soliman I, Brathwaite E, Shoenfeld Y (2016) Vitamin D and autoimmunity. Scand J Rheumatol 45:439-447

17. Holick MF (2007) Vitamin D deficiency. N Engl J Med 357:266-281

18. Peelen E, Knippenberg S, Muris AH, Thewissen M, Smolders J, Tervaert JW, Hupperts R, Damoiseaux J (2011) Effects of vitamin $\mathrm{D}$ on the peripheral adaptive immune system: a review. Autoimmun Rev 10:733-743. doi:10.1016/j.autrev.2011.05.002

19. Chen S, Sims GP, Chen XX, Gu YY, Lipsky PE (2007) Modulatory effects of 1,25-dihydroxyvitamin D3 on human B cell differentiation. J Immunol 179:1634-1647

20. Watad A, Quaresma M, Brown S, Cohen Tervaert JW, RodríguezPint I, Cervera R, Perricone C, Shoenfeld Y (2017) Autoimmune/ inflammatory syndrome induced by adjuvants (Shoenfeld's syndrome) — an update. Lupus. doi:10.1177/0961203316686406

21. Damoiseaux JG, Tervaert JW (2006) From ANA to ENA: how to proceed? Autoimmun Rev 5:10-17

22. Tervaert JW, van der Woude FJ, Fauci AS, Ambrus JL, Velosa J, Keane WF, Meijer S, van der Griessen M, van der Hem GK, The TH et al (1989) Association between active Wegener's granulomatosis and anticytoplasmic antibodies. Arch Intern Med 149:2461-2465

23. Drijkoningen J, Damoiseaux J, van Paassen P, Tervaert JW (2007) Clinical manifestations of the anti-phospholipid syndrome as defined by the updated Sapporo classification criteria. Ann Rheum Dis 66:1407-1408

24. Tervaert JW, Van Paassen P, Damoiseaux J (2007) Type II cryoglobulinemia is not associated with hepatitis $\mathrm{C}$ infection: the Dutch experience. Ann N Y Acad Sci 1107:251-258

25. Cohen Tervaert JW, Damoiseaux J (2012) Antineutrophil cytoplasmic autoantibodies: how are they detected and what is their use for diagnosis, classification and follow-up? Clin Rev Allergy Immunol 43:211-219. doi:10.1007/s12016-012-8320-4

26. Avery TY, van de Cruys M, Austen J, Stals F, Damoiseaux JG (2014) Anti-nuclear antibodies in daily clinical practice: prevalence 
in primary, secondary, and tertiary care. J Immunol Res 2014: 401739. doi: $10.1155 / 2014 / 401739$

27. De Steenwinkel FD, Hokken-Koelega AC, de Ridder MA, Hazes JM, Dolhain RJ (2014) Rheumatoid arthritis during pregnancy and postnatal catch-up growth in the offspring. Arthritis Rheumatol 66: 1705-1711. doi:10.1002/art.38519

28. Holick MF, Binkley NC, Bisschoff-Ferrari HA, Gordon GM, Hanley DA, Heaney RP, Murad MH, Weaver CM, Endocrine Society (2011) Evaluation, treatment, and prevention of vitamin D deficiency: an endocrine society clinical practice guideline. J Clin Endocrin Metab 96:1911-1930. doi:10.1210/jc.2011-0385

29. Cashman KD, Dowling KG, Skrabákova Z, Gonzales-Gross M, Valtueña J, De Henauw S et al (2016) Vitamin D deficiency in Europe: pandemic? Am J Clin Nutr 103:1033-1044. doi:10.3945/ ajcn.115.120873

30. Wang J, Shishi LV, Chen G, He J, Zhong H, Xu Y (2015a) Metaanalysis of the association between vitamin $\mathrm{D}$ and autoimmune thyroid disease. Nutrients 7:2485-2498. doi:10.3390/nu7042485

31. Kivity S, Agmon-Levin N, Zisappl M, Shapira Y, Nagy EV, Dankó K, Szekanecz Z, Langevitz P, Shoenfeld Y (2011) Vitamin D and autoimmune thyroid diseases. Cell Mol Immunol 8:243-247. doi: 10.1038/cmi.2010.73

32. Choi YM, Kim WG, Kim TY, Bae SJ, Kim HK, Jang EK et al (2014) Low levels of serum vitamin D3 are associated with autoimmune thyroid disease in pre-menopausal women. Thyroid 24: 655-661. doi:10.1089/thy.2013.0460

33. Goswami R, Marwaha RK, Gupta N, Tandon N, Screenivas V, Tomar N, Ray D, Kanwar R, Agarwai R (2009) Prevalence of vitamin $\mathrm{D}$ deficiency and its relationship with thyroid autoimmunity in Asian Indians: a community-based survey. Br J Nutr 102:382386. doi:10.1017/S0007114509220824

34. Arslan MS, Topaloglu O, Ucan B, Karakose M, Karbek B, Tutal E et al (2015) Isolated vitamin D deficiency is not associated with nonthyroidal illness syndrome, but with thyroid autoimmunity. Scientific WorldJournal. doi:10.1155/2015/239815

35. Unal AD, Tarcin O, Parildar H, Cigerli O, Eroglu H, Demirag NG (2014) Vitamin D deficiency is related to thyroid antibodies in autoimmune thyroiditis. Cent Eur J Immunol 39:493-497. doi:10. 5114/ceji.2014.47735

36. Mazokopakis EE, Papadomanolaki MG, Tsekouras KC, Evangelopoulos AD, Kotsiris DA, Tzortzinis AA (2015) Is vitamin D related to pathogenesis and treatment of Hashimoto's thyroiditis? Hell J Nucl Med 18:222-227

37. Bozkurt NC, Karbek B, Ucan B, Sahin M, Cakal E, Ozbek M, Delibasi T (2013) The association between severity of vitamin D deficiency and Hashimoto's thyroiditis. Endocr Pract 19:479-484. doi:10.4158/EP12376.OR

38. Shin DY, Kim KJ, Kim D, Hwang S, Lee EJ (2014) Low serum vitamin $\mathrm{D}$ is associated with anti-thyroid peroxidase antibody in autoimmune thyroiditis. Yonsei Med J 55:476-481. doi:10.3349/ymj.2014.55.2.476

39. Wang X, Zynat J, Osiman R, Tuhuti A, Abdunaimu M, Wang H, Jin $\mathrm{X}$, Xing S (2015b) Low serum vitamin D is associated with antithyroid-globulin antibody in female individuals. Int J Endocrinol. doi:10.1155/2015/285290

40. Krysiak R, Kowalcze K, Okopien B (2016) The effect of vitamin D on thyroid autoimmunity in non-lactating women with postpartum thyroiditis. Eur J Clin Nutr 70:637-639. doi:10.1038/ejen.2015.214

41. D'Aurizio F, Villalta D, Metus P, Doretto P, Tozzoli R (2015) Is vitamin $\mathrm{D}$ a player or not in the pathophysiology of autoimmune thyroid diseases? Autoimmun Rev 14:363-369. doi:10.1016/j. autrev.2014.10.008

42. Ma J, Wu D, Li C, Fan C, Chao N, Liu J, Li Y, Wang R et al (2015) Lower serum 25-hydroxyvitamin $\mathrm{D}$ level is associated with 3 types of autoimmune thyroid diseases. Medicine (Baltimore). doi:10. 1097/MD.0000000000001639
43. Yasuda T, Okamoto Y, Hamada N, Miyashita K, Takahara M, Sakamoto F et al (2012) Serum vitamin D levels are decreased and associated with thyroid volume in female patients with newly onset Graves' disease. Endocrine 42:739-741. doi:10.1007/ s12020-012-9679-y

44. Muscogiuri G, Palomba S, Caggiano M, Tafuri D, Colao A, Orio F (2016) Low $25(\mathrm{OH})$ vitamin D levels are associated with autoimmune thyroid disease in polycystic ovary syndrome. Endocrine 53: 538-542. doi:10.1007/s12020-015-0745-0

45. Effraimidis G, Badenhoop K, Tijssen JG, Wiersinga WM (2012) Vitamin D deficiency is not associated with early stages of thyroid autoimmunity. Eur J Endocrinol 167:43-48. doi:10.1530/EJE-12-0048

46. Ritterhouse LL, Crowe SR, Niewold TB, Kamen DL, Macwana SR, Roberts VC et al (2011) Vitamin D deficiency is associated with an increased autoimmune response in healthy individuals and in patients with systemic lupus erythematosus. Ann Rheum Dis 70:1569-1574. doi:10.1136/ard.2010.148494

47. Schneider L, Dos Santos AS, Santos M, da Silva Chakr RM, Monticielo OA (2014) Vitamin D and systemic lupus erythematosus: state of the art. Clin Rheumatol 33:1033-1038. doi:10.1007/s10067-014-2530-5

48. Szodoray P, Tarr T, Bazco A, Poor G, Szegedi G, Kiss E (2011) The immunopathological role of vitamin D in patients with SLE: data from a single centre registry in Hungary. Scand J Rheumatol 40: 122-126. doi:10.3109/03009742.2010.507220

49. Costenbader KH, Feskanich D, Holmes M, Karlson EW, Benito-Garcia E (2008) Vitamin D intake and risks of systemic lupus erythematosus and rheumatoid arthritis in women. Ann Rheum Dis 67:530-535

50. Bonakdar ZS, Jahanshahifar L, Jahanshahifar F, Gholamrezaei A (2011) Vitamin D deficiency and its association with disease activity in new cases of systemic lupus erythematosus. Lupus 20:11551160. doi:10.1177/0961203311405703

51. Mok CC, Birmingham DJ, Ho LY, Hebert LA, Song H, Rovin BH (2012) Vitamin D deficiency as marker for disease activity and damage in systemic lupus erythematosus: a comparison with anti-dsDNA and anti-C1q. Lupus 21:36-42. doi:10.1177/0961203311422094

52. Thudi A, Yin S, Wandstrat AE, Li QZ, Olsen NJ (2008) Vitamin D levels and disease status in Texas patients with systemic lupus erythematosus. Am J Med Sci 335:99-104. doi:10.1097/MAJ. 0b013e318134eeb6

53. AlSaleem A, AlE'ed A, Alsaghier A, Al-Mayouf SM (2015) Vitamin D status in children with systemic lupus erythematosus and its association with clinical and laboratory parameters. Clin Rheumatol 34:81-84. doi:10.1007/s10067-014-2811-z

54. Müller K, Oxholm P, Sorensen OH, Thymann M, Hoier-Madsen M, Bendtzen K (1990) Abnormal vitamin D3 metabolism in patients with primary Sjögren's syndrome. Ann Rheum Dis 49:682-684

55. Hajas A, Sandor J, Csathy L, Csipo I, Barath S, Paragh G, Seres I, Szegedi G, Shoenfeld Y, Bodolay E (2011) Vitamin D insufficiency in a large MCTD population. Autoimmun Rev 10:317-324. doi:10. 1016/j.autrev.2010.11.006

56. Zold E, Szodoray P, Gaal J, Kappelmayer J, Csathy L, Gyimesi E, Zeher M, Szegedi G, Bodolay E (2008) Vitamin D deficiency in undifferentiated connective tissue disease. Arthritis Res Ther. doi: 10.1186/ar2533

57. Paupitz JA, Freire de Carvalho J, Caparbo VF, Klack K, Pereira RM (2010) Primary antiphospholipid syndrome in premenopausal women: low vitamin $\mathrm{D}$, high fat mass, and maintained bone mineral mass. Lupus 19:1302-1306. doi:10.1177/0961203310372938

58. Arnson Y, Amital H, Agmon-Levin N, Alon D, Sanchez-Castan M, Lopez-Hoyos M et al (2011) Serum 25-OH vitamin D concentrations are linked with various clinical aspects in patients with systemic sclerosis: a retrospective cohort study and review of the literature. Autoimmun Rev 10:490-494. doi:10.1016/j.autrev.2011.02.002

59. Merlino LA, Curtis J, Mikuls TR, Cerhan JR, Criswell LA, Saag KG (2004) Vitamin D intake is inversely associated with lower risk 
of rheumatoid arthritis in older women: results from the Iowa women's health study. Arthritis Rheum 50:72-77

60. Nielen NM, van Schaardenburg D, Lems WF, van de Stadt RJ, Reesink HW, Habibuw MR, van der Horst-Bruinsma IE, Twisk JW, Dijkmans BA (2006) Vitamin D deficiency does not increase the risk of rheumatoid arthritis; comment on the article by Merlino et al. Arthritis Rheum 54:3719-3720

61. Feser M, Derber LA, Daene KD, Lezotte DC, Weisman MH, Buckner JH et al (2009) Plasma 25,OH vitamin D concentrations are not associated with rheumatoid arthritis (RA)-related autoantibodies in individuals at elevated risk for RA. J Rheumatol 36:943946. doi:10.3899/jrheum.080764

62. Haga HJ, Schmedes A, Naderi Y, Moreno AM, Peen E (2013) Severe deficiency of 25-hydroxyvitamin $\mathrm{D}_{3}\left(25-\mathrm{OH}-\mathrm{D}_{3}\right)$ is associated with high disease activity of rheumatoid arthritis. Clin Rheumatol 32:629-633. doi:10.1007/s10067-012-2154-6

63. Urruticoechea-Arana A, Martín-Martínez MA, Castañeda S, Piedra CA, González-Juanatey C, Llorca J, Díaz-Gonzalez F, GonzálezGay MA, CARMA Project Collaborative Group (2015) Vitamin D deficiency in chronic inflammatory rheumatic diseases: results of the cardiovascular in rheumatology [CARMA] study. Arthritis Res Ther. doi:10.1186/s13075-015-0704-4

64. Teichman J, Voglau MJ, Lange U (2010) Antibodies to human tissue transglutaminase and alterations of vitamin D metabolism in ankylosing spondylitis and psoriatic arthritis. Rheumatol Int 30: 1559-1563. doi:10.1007/s00296-009-1186-y

65. Salzer J, Hallmans G, Nyström M, Stenlund H, Wadell G, Sundström P (2012) Vitamin D as a protective factor in multiple sclerosis. Neurology 79:2140-2145. doi:10.1212/WNL.0b013e3182752ea8

66. Smolders J (2010) Vitamin D and multiple sclerosis: correlation, causality, and controversy. Autoimmune Dis. doi:10.4061/2011/629538

67. Smolders J, Peelen E, Thewissen M, Cohen Tervaert JW, Menheere P, Hupperts R, Damoiseaux J (2010) Safety and T cell modulating effects of high dose vitamin D3 supplementation in multiple sclerosis. PLoS One. doi:10.1371/journal.pone.0015235

68. Smolders J, Hupperts R, Barkhof F, Grimaldi LM, Holmoy T, Killesetin J et al (2011) Efficacy of vitamin D3 as add-on therapy in patients with relapsing-remitting multiple sclerosis receiving subcutaneous interferon $\beta$-1a: a phase II, multicenter, double-blind, randomized, placebo-controlled trial. J Neurol Sci 311:44 49. doi:10.1016/j. jns.2011.04.013

69. Mowry EM, James JA, Krupp LB, Waubant E (2011) Vitamin D status and antibody levels to common viruses in pediatric-onset multiple sclerosis. Mult Scler 17:666-671. doi:10.1177/1352458510394398

70. Rolf L, Muris AH, Hupperts R, Damoiseaux J (2016) Iluminating vitamin D effects of B-cells - the multiple sclerosis perspective. Immunology 147:275-284. doi:10.1111/imm. 12572

71. Levin LI, Munger KL, Rubertone MV, Peck CA, Lennette ET, Spiegelman D, Ascherio A (2005) Temporal relationship between elevation of Epstein-Barr virus antibody titers and initial onset of neurological symptoms in multiple sclerosis. JAMA 293:2496-2500

72. Salzer J, Nyström M, Hallmans G, Stenlund H, Wadell G, Sundström P (2013) Epstein-Barr virus antibodies and vitamin D in prospective multiple sclerosis biobank samples. Mult Scler 19: 1587-1591. doi:10.1177/1352458513483888

73. Décard BF, von Ahsen N, Grunwald T, Streit F, Stroet A, Niggemeier P, Schottstedt V, Riggert J, Gold R, Chan A (2012) Low vitamin D and elevated immunoreactivity against Epstein-Barr virus before first clinical manifestation of multiple sclerosis. J Neurol Neurosurg Psychiatry 83:1170-1173. doi:10.1136/jnnp-2012-303068

74. Disanto G, Handel AE, Damoiseaux J, Hupperts R, Giovannoni G, Smolders J, Ramagopalan SV (2013) Vitamin D supplementation and antibodies against the Epstein-Barr virus in multiple sclerosis patients. Mult Scler 19:1679-1680. doi:10.1177/1352458513494494

75. Najafipoor A, Roghanian R, Zarkesh-Esfahani SH, Bouzari M, Etemadifar M (2015) The beneficial effects of vitamin D3 on reducing antibody titers against Epstein-Barr virus in multiple sclerosis patients. Cell Immunol 294:9-12. doi:10.1016/j.cellimm.2015.01.009

76. Kabbani TA, Koutroubakis IE, Schoen RE, Ramos-Rivers C, Shah N, Swoger J et al (2016) Association of vitamin D level with clinical status in inflammatory bowel disease: a 5-year longitudinal study. Am J Gastroenterol 111:712-719. doi:10.1038/ajg.2016.53

77. Santos-Antunes J, Nunes AC, Lopes S, Macedo G (2016) The relevance of vitamin $D$ and antinuclear antibodies in patients with inflammatory bowel disease under anti-TNF treatment: a prospective study. Inflamm Bowel Dis 22:1101-1106. doi:10.1097/MIB. 0000000000000697

78. Ribeiro SL, Pereira HL, Mangueira CL, Ferreira CE, Rosseto E, Scheinberg M (2012) The development of arthritis and antinuclear antibodies correlate with serum 25-hydroxyvitamin D levels in patients with leprosy. Ann Rheum Dis 71:2062-2063. doi:10.1136/ annrheumdis-2012-201485

79. Nuti R, Martini G, Valenti R, Giovani S, Salvadori S, Avanzati A (2001) Prevalence of undiagnosed coeliac syndrome in osteoporotic women. J Intern Med 250:361-366

80. Karakan T, Ozyemisci-taskiran O, Gunendi Z, Atalay F, Tuncer C (2007) Prevalence of IgA-antiendomysial antibody in a patient cohort with idiopathic low bone mineral density. World J Gastroenterol 13:2978-2982

81. Ota K, Dambaeva S, Han AR, Beaman K, Gilman-Sachs A, KwakKim J (2014) Vitamin D deficiency may be a risk factor for recurrent pregnancy losses by increasing cellular immunity and autoimmunity. Hum Reprod 29:208-219. doi:10.1093/humrep/det424

82. Njemini R, Meyers I, Demanet C, Smitz J, Sosso M, Mets T (2002) The prevalence of autoantibodies in an elderly sub-Saharan African population. Clin Exp Immunol 127:99-106

83. Carvalho JF, Blank M, Kiss E, Tarr T, Amital H, Shoenfeld Y (2007) Anti-vitamin D, vitamin D in SLE: preliminary results. Ann N Y Acad Sci 1109:550-557

84. Barrea L, Savanelli MC, Di Somma C, Napolitano M, Megna M, Colao A, Savastano S (2017) Vitamin D and its role in psoriasis: an overview of the dermatologist and nutritionist. Rev Endocr Metab Disord. doi:10.1007/s11154-017-9411-6

85. Rolf R, Muris AH, Hupperts R, Damoiseaux J (2014) Vitamin D effects on B cell function in autoimmunity. Ann N U Acad Sci 1317:84-91. doi:10.1111/nyas.12440

86. Holmoy T, Lossius A, Gundersen TE, Moen SM, Castellazzi M, Fainardi E, Casetta I (2012) Intrathecal levels of vitamin D and IgG in multiple sclerosis. Acta Neurol Scand 125:e28-e31

87. Knippenberg S, Smolders J, Thewissen PE, Tervaert JW, Hupperts R, Damoiseaux J (2011) Effect of vitamin D(3) supplementation on peripheral $\mathrm{B}$ cell differentiation and isotype switching in patients with multiple sclerosis. Mult Scler 17:1418-1423. doi:10.1177/1352458511412655

88. Peelen E, Rijkers G, Meerveld-Eggink A, Meijvis S, Vogt M, Cohen Tervaert JW, Hupperts R, Damoiseaux J (2013) Relatively high serum vitamin $\mathrm{D}$ levels do not impair the antibody response to encapsulated bacteria. Eur J Clin Microbiol Infect Dis 32:61-69. doi:10.1007/s10096-012-1714-7

89. Ben-Zvi I, Aranow C, Mackay M, Stanevsky A, Kamen DL, Marinescu M, Collins CE, Gilkeson GS, Diamond B, Hardin JA (2010) The impact of vitamin D on dendritic cell function in patients with systemic lupus erythematosus. PLoS One. doi:10.1371/ journal.pone.0009193 